These and other requirements have been clearly set forth by Dr. R. S. Hutton in a paper contributed to a symposium in the Journal of Documentation for March 1961 , and they will bear re-examination in the discussions on the new Bill. Useful as it may be to remove obsolete procedures and to free the British Museum, Bloomsbury, from restrictions of the past, including its close linking with the British Museum (Natural History), all this is only the first stage. It clears the way and gives the opportunity. Whether the opportunities are fully used depends on the vision and determination which are brought to bear, on the resources which the Government make available, and on the extent of the support and co-operation which is forthcoming from other libraries and institutions and from a wide range of scientists, technologists and scholars and their professional institutions.

\section{ALFRED NOBEL}

Nobel: The Man and His Prizes

By H. Schuck, R. Sohlman, A. Osterling, G. Liljestrand, A. Westgren, M. Siegbahn, A. Schou and N. K. Stahle. Edited by the Nobel Foundation. Pp. $x+690$. (Amsterdam and London: Elsevier Publishing Company, 1962.) $60 s$.

HIS huge volume, published under the auspices of the Nobel Foundation, gives an account of the life of Alfred Nobel and a full list of the prizewinners with comments on the achievements for which they received the award.

It is intended to issue within the next two years nine other volumes giving in full the Nobel Lectures in English up to 1961 with the address on the presentation of the awards and a biographical account of the prizewinner. Beginning with 1962, this full account of the awards will be given in annual year-books.

The story of the life of Alfred Nobel, based on all available documents, letters and information and impressions gained from his associates, is the most authentic account which has so far been written. It depicts a rather sensitive, lonely man of quite extraordinary ability and a high appreciation of the spiritual values in life. Though he had only a fragmentary education which ended when he was sixteen, he spoke and wroto fluently in English, French and German in addition to Russian and Swedish. His researches and inventions entitled him to the highest rank of scientists. He had also great financial ability. After losing his fortune through the fraudulence of his partners ho built up another fortune which enabled him to establish the Nobel Foundation.

Probably the most intoresting aspect of his life was his high idealism. Though he repudiated the Christian religion, which he thought had brought persecution and suffering to so many, and could not believe in a God who would inflict punishment for all eternity on suffering mortals, he was filled with awe and reverence for the mystery of life and a love for his fellow men, with an infinite compassion for unnecessary poverty and suffering.

$\mathrm{He}$ predicted that the science in which he was engaged would produce weapons of such destructive power that war would become impossible. He wrote: "When two army corps can annihilate each other in a second, all civilized nations, it is to be hoped, will recoil from war and discharge their troops". Modern nuclear and biological weapons have proved the truth of his prediction so far as the results in war are now concerned, but unfortunately civilized nations have not yet recoiled and agreed to settle their differences by peaceful means.

The rest of the book consists of the list of all the awards given since the Foundation was established in 1901 with an account of the achievements for which the awards were given. This interesting account affords a review of the great advance in science made since the beginning of the present century.

The Peace Prizes given for efforts made to realize Nobel's ideal of the end of war give interesting glimpses of international polities in the present contury.

Such is the account of the life and achievements of a great idealist who devoted his life and his fortune to the promotion of human welfare. BOyd ORR

\section{THE STUDY OF MAN}

They Studied Man

By Abram Kardiner and Edward Preble. Pp. 287. (London: Secker and Warburg, Ltd., 1962.) 25s. net.

$\mathrm{O}^{\mathrm{n}}$ $\mathrm{NE}$ of the authors of this book is a psychoanalyst who worked with Freud and has taught both anthropology and sociology; the other is an anthropologist in a school of psychology. The result is that this set of biographical essays comprises studies not only of the founder of psychoanalysis but also of six anthropologists: Tylor, Frazer, Boas, Malinowski, Kroeber and Ruth Benedict; a biologist, Charles Darwin; and two sociologists, Herbert Spencer and Durkheim. The essays combine useful biographical details with a certain amount of gossip and some shrewd observations on the scientific achievements of each of the subjects. Despite the rather arch titles of the chapters, for example, "Boas: Icy Enthusiasm"; "Freud: Chimney Sweeping", and the triviality of some of the material, each essay does help to throw some new light on the way in which the man concerned did his work.

The idea of the book is not to give a history of anthrop. ology but to relate the "seminal hypotheses" of the "few great innovators" in the development of the science of man to the events of their lives and the spirit of the times. The main theme throughout the book is human adaptation, and the birth and growth of the scientific tradition of the study of human culture is presented within this framework. The hypotheses, theories and techniques of the scientists examined are represented as being essentially responses to the collective interests and needs of their time. Idiosyncracy and genius are not denied, but are treated as being on the individual level, not on the cultural level.

The book is an interesting argument for the importance of the study of the impact of institutions and cultural change on the human mind in modern times, and for the need for the development of techniques for measuring the effect of these changes on man. From this point of view it is an attempt to bring psychology and anthropology more closely together. But the final chapters on the significance of psycho-dynamics for the investigation of culture are not very convincing. The attempt to illiustrate the usefulness of psycho-dynamics by explaining how scientific interest in man and culture "happened to develop in the nineteenth century" is not much more than a rather weak piece of social history.

R. FirTh

\section{HUSSERL'S PSYCHOLOGY}

\section{Phänomenologische Psychologie}

Vorlesungen Sommersemester 1925. Von Edmund Husserl. Herausgegeben von Walter Biemel. (Husserliana, Band 9.) Pp. xxviii +650 . (The Hague: Martinus Nijhoff, 1962.) 31 guilders, paper; 37 guilders, cloth.

THE appearance of Volume 9 of Husserliana under the editorship of Dr. Walter Biomel is an occasion of special significance. $\mathrm{He}$ is now laying down his task after some fifteen years of close association with the 